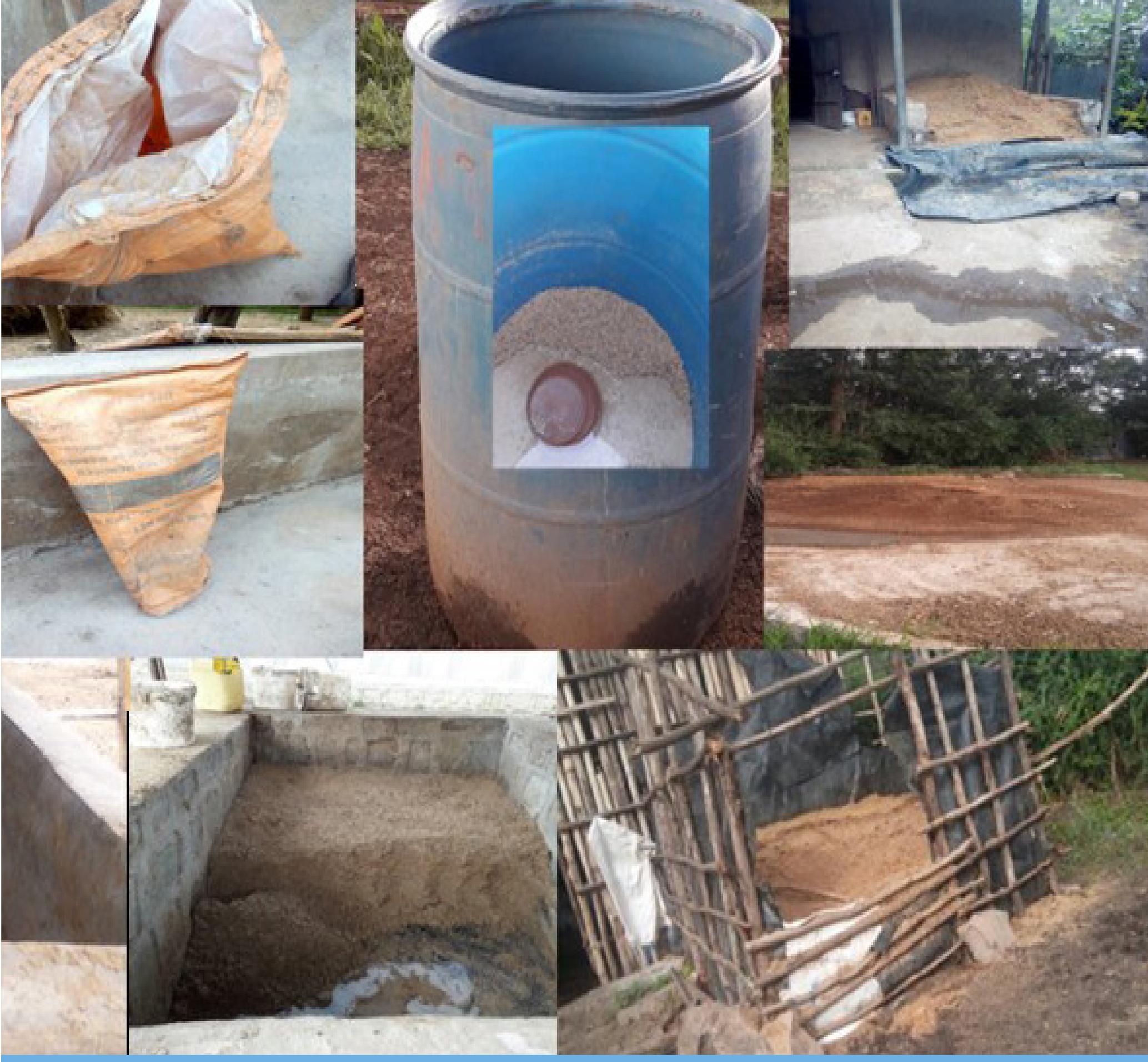

Utilization and management of spent brewers grain in Ethiopian dairy farms

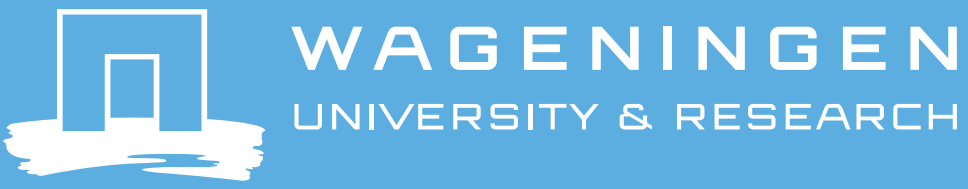





\section{Utilization and management of spent brewers grain in Ethiopian dairy farms}

Adolfo Alvarez Aranguiz ${ }^{1}$, Tinsae Berhanu² and Adriaan Vernooij ${ }^{1}$

1 Wageningen Livestock Research

2 DairyBISS Project

This research was carried out by Wageningen Livestock Research, as part of the implementation of the DairyBISS (Dairy Business Information and Support Service) Project in Ethiopia, financed by the Food Security Program of the Netherlands Ministry of Foreign Affairs. 
Adolfo Alvarez Aranguiz, Tinsae Berhanu and Adriaan Vernooij, 2019. Utilization and management of spent brewers grain in Ethiopian dairy farms. Wageningen Livestock Research, Report 1207.

This report can be downloaded for free at https://doi.org/10.18174/504103 or at www.wur.nl/livestock-research (under Wageningen Livestock Research publications).

(C) 2019 Wageningen Livestock Research

P.O. Box 338, 6700 AH Wageningen, The Netherlands, T +31 (0)317 4839 53, E

info.livestockresearch@wur.nl, www.wur.nl/livestock-research. Wageningen Livestock Research is part of Wageningen University \& Research.

All rights reserved. No part of this publication may be reproduced and/or made public, whether by print, photocopy, microfilm or any other means, without the prior permission of the publisher or author.

Wageningen Livestock Research is NEN-EN-ISO 9001:2015 certified.

All our research commissions are in line with the Terms and Conditions of the Animal Sciences Group. These are filed with the District Court of Zwolle.

Wageningen Livestock Research Report 1207 


\section{Content}

$\begin{array}{ll}\text { Executive summary } & 5\end{array}$

1

$\begin{array}{ll}\text { General Background } & 6\end{array}$

2

$\begin{array}{ll}\text { Field survey } & 10\end{array}$

2.1 Materials and Methods $\quad 10$

2.1.1 The Study Areas $\quad 10$

2.1.2 Data Collection $\quad 10$

2.1.3 Analysis 11

2.2 Results and Discussion $\quad 11$

2.2.1 Factory and Supplier 11

$\begin{array}{ll}2.2 .2 \text { Price } & 12\end{array}$

$\begin{array}{ll}2.2 .3 \text { Frequency } & 13\end{array}$

2.2.4 Storage and Conservation 13

$\begin{array}{ll}2.2 .5 \text { Feeding } & 14\end{array}$

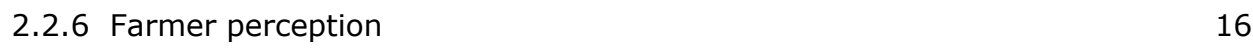

3

$\begin{array}{ll}\text { Conclusions } & 17\end{array}$

$\begin{array}{ll}\text { References } & \mathbf{2 0}\end{array}$

Annexe 1 Questionnaire to collect data on brewer's grain utilization from sample dairy farms

Annexe 2 Spent Brewery Grain Nutritional Characteristics to be considered under Ethiopian Dairy System Conditions

Annexe 3 Silage

Annexe 4 Feeding management

Annexe 5 Feed budgeting 



\section{Executive summary}

This report is based on the information generated through a survey, meetings with stakeholders, visits to farms, and research information already available to the organisation. The acquired knowledge has provided a realistic view of how dairy systems in the study areas in Ethiopia are managed and allowed the realisation of an analysis of the situation at the farm level. This information has then been used to propose the development of future actions so that the efficiency in the utilization of the spent brewery grain on Ethiopia dairy farms is optimised.

The presence of numerous breweries in the area studied with a potential capacity of $10,660.000 \mathrm{hl}$ of beer per year and their projected growth in the near future, offers an excellent opportunity to farmers in the area to have access to spent brewery grain at a very affordable price.

The information gathered in this study reveals that spent brewery grain is a key ingredient in the dairy cow's diet in Ethiopia, especially considering the scarcity of land to grow fodders and the quality of available feed. Yet the efficiency at which this by-product is currently utilised is very low. In order to improve the efficiency of its use it will be fundamental to take action in different aspects of the production chain, as listed below:

- Improvement of the commercialization chain: At present there is a lack of transparency in the chain, along with transport issues and the lack of compromise of the stakeholders involved. This situation limits the ability of farmers to develop a feed budget based in the spent brewery grain utilization.

- Storage: Condition and capacity of storage are the main on-farm limitations. Key aspects that will need to be addressed are the improvement of the storage infrastructure and their capacity. The possibility to make silage of spent brewery grain, alone or combined with other feeds, can be an interesting option to be considered.

- Management: There is a manifest lack of knowledge and information on how to manage this byproduct, and especially on how to avoid spoilage and heating. Farmers are requesting information to overcome these issues.

- $\quad$ Feeding: The current inefficient use of spent brewery grain as a component of the diet of dairy cows is due to a combination of factors which includes not only those just mentioned, but also the lack of knowledge on the nutritional properties of the spent brewery grain and its potential use as an ingredient in the complete diet.

According to the information gathered, we can conclude that spent brewery grain is a key ingredient in the diet of dairy cows of the study area and will be a crucial component in the profitability of the Ethiopian dairy farms in the future. The nutrient content of spent brewery grain combined with the low-quality feed available for dairy cows will allow to improve the expression of the animal genetic potential, increment their productivity, and improve animal condition. At the same time, the competitive price of the by-product will help improve the profitability of the dairy farm. 


\section{$1 \quad$ General Background}

Feed and feeding problems faced by the dairy sector in Ethiopia are:

- Scarcity of land for fodder production

- Insufficient quantity and quality forage

- Very low digestible forage available

- Insufficient inputs for commercial feed

- Unbalanced rations

- Absence of feed testing

- Inefficient feed utilization

According to the statistics of the Ethiopian Government, grazing land availability is shrinking fast, from $30 \%$ of the land cover in 1980 to $12 \%$ in 2000.

Over the last decade, as the economy has begun to grow, Ethiopia has experienced one of the fastest increases of beer consumption in the recent years, with consumption growing by as much as 90 percent between 2002 and 2011 (FAO, 2014*). Ethiopia's beer consumption per capita is about $4.0 \mathrm{I}$, which it is relatively low when compared with Kenya (11.0 I), Uganda (9.5 I), and South Africa (55 I) $\left(\mathrm{FAO}, 2011^{*}\right)$, and thus has a big potential to increase.

This increment in beer consumption has produced a rapid expansion of brewery factories and spent brewery grain has become an alternative feedstuff for dairy producers in areas close to the breweries, contributing to decrease the feeding cost and increase the production due the nutritional quality of the by-product.

According to "FAO feed balance" (in preparation, unpublished data) the estimated total feed deficiency in Ethiopia of $1.045 .000 \mathrm{t}$ of dry matter per year (without including industrial by-products), thus spent brewery grain can play a significant role in reducing this negative balance.

Given that the demand for spent brewery grain is growing more than the supply, spent brewery grain prices could rise in the near future, and this has to be taken in consideration in future strategies. Therefore, the study of the actual on-farm situation through a survey should provide the information needed for the development of a proposal on future actions to be taken for a more efficient management and use of spent brewery grain in Ethiopian dairy farms.

\section{BREWERIES}

The industry has responded to the growing demand by expanding their scale of operation. The Government invited two of the world's largest breweries (i.e., Heineken and Diageo) to set up operations and now more pilot plants are underway to promote the production of malt barley. For instance, the Dashen Brewery, one of the holding companies in the country, is quadrupling its production capacity (from 1 million $\mathrm{hl}$ to 4 million $\mathrm{hl}$ ) and exploring options for domestic sourcing. Similarly, other breweries are also trying to develop their own value chain. In addition, there is now growing evidence that, with an increase in income, households are switching from domestically brewed beverages (e.g., Tella and Areki) to bottled beer. Since traditional beer is sorghum- and other grain-based, and the bottled beers are barley-based, this has further accelerated the demand for malt barley (Tura et al. 2015).

The actual potential capacity of the breweries in the studied area (Table 1 ) is around 10.660.000 $\mathrm{hl}$ of beer and can generate between 160.000-320.000 t of spent brewery grain residual and 20.000 to 28.000 t of yeast waste. Based in the breweries production capacity, the spent brewery grain produced can be enough to feed 60.000 cows with $10 \mathrm{~kg} /$ day throughout the year. 
Table 1 Ethiopian Breweries Production Capacity.

\begin{tabular}{llll} 
Brewery & Beer Production Capacity & Spent Brewery Grain & Spent Brewery Yeast \\
& (Hectolitres) & (Tonnes & (Tonnes \\
& & Wet Weight*) & Weight*) \\
\hline Raya Brewery & 600000 & 12000 & 1200 \\
\hline Habesha & 650000 & 13000 & 1300 \\
\hline Meta & 1000000 & 20000 & 2000 \\
\hline Bedele & 500000 & 10000 & 1000 \\
\hline Harrar & 450000 & 9000 & 900 \\
\hline Waliya & 1500000 & 30000 & 3000 \\
\hline Dashen & 2900000 & 58000 & 5800 \\
\hline St George & 3000000 & 60000 & 6000 \\
\hline Zebider & 60000 & 1200 & 120 \\
\hline Total & 10660000 & 213200 & 21320 \\
\hline
\end{tabular}

*Calculated based on $20 \mathrm{~kg}$ spent brewery grain and $2 \mathrm{~kg}$ spent brewery yeast / hl beer produced (Mathias et al., 2014)

\section{BREWERY BYPRODUCTS}

The main by-products from breweries that can be used as animal feed are spent brewery grain and spent brewery yeast (Figure 1). This report is mainly focusing on the potential of spent brewery grain as an ingredient in the feed of Ethiopian dairy farms.

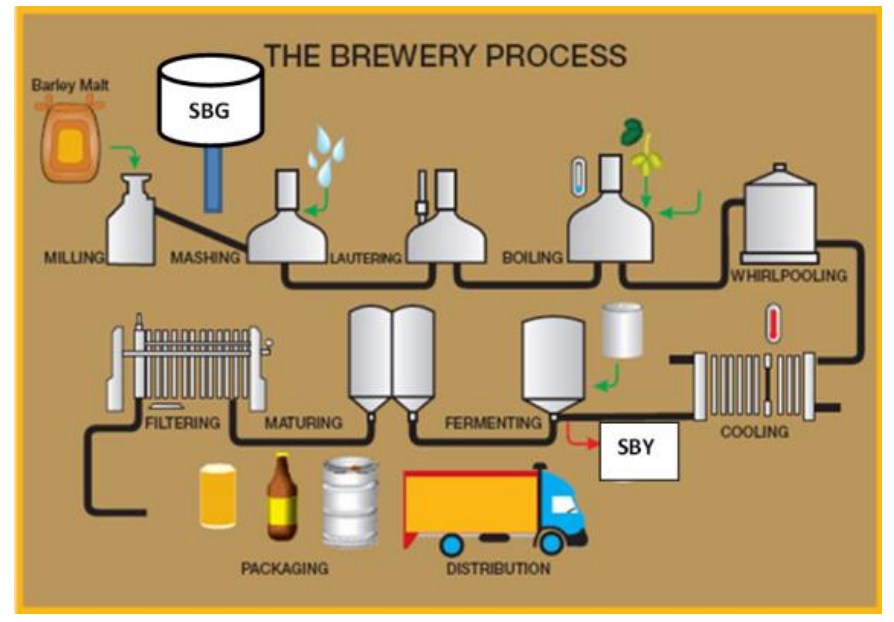

Figure 1 The brewery process.

Spent Brewers Grain

The use of spent brewery grain to feed dairy cows is very well known around the word, and a lot of research has been carried out on of this matter. The nutrient content of this by-product (Table 2) makes it a very interesting ingredient for the feed of dairy cows. 
Table 2 Nutritional composition of wet spent brewery grain in Ethiopia (Feyissa et al, 2015, Solomon, 2007) expressed on DM\%.

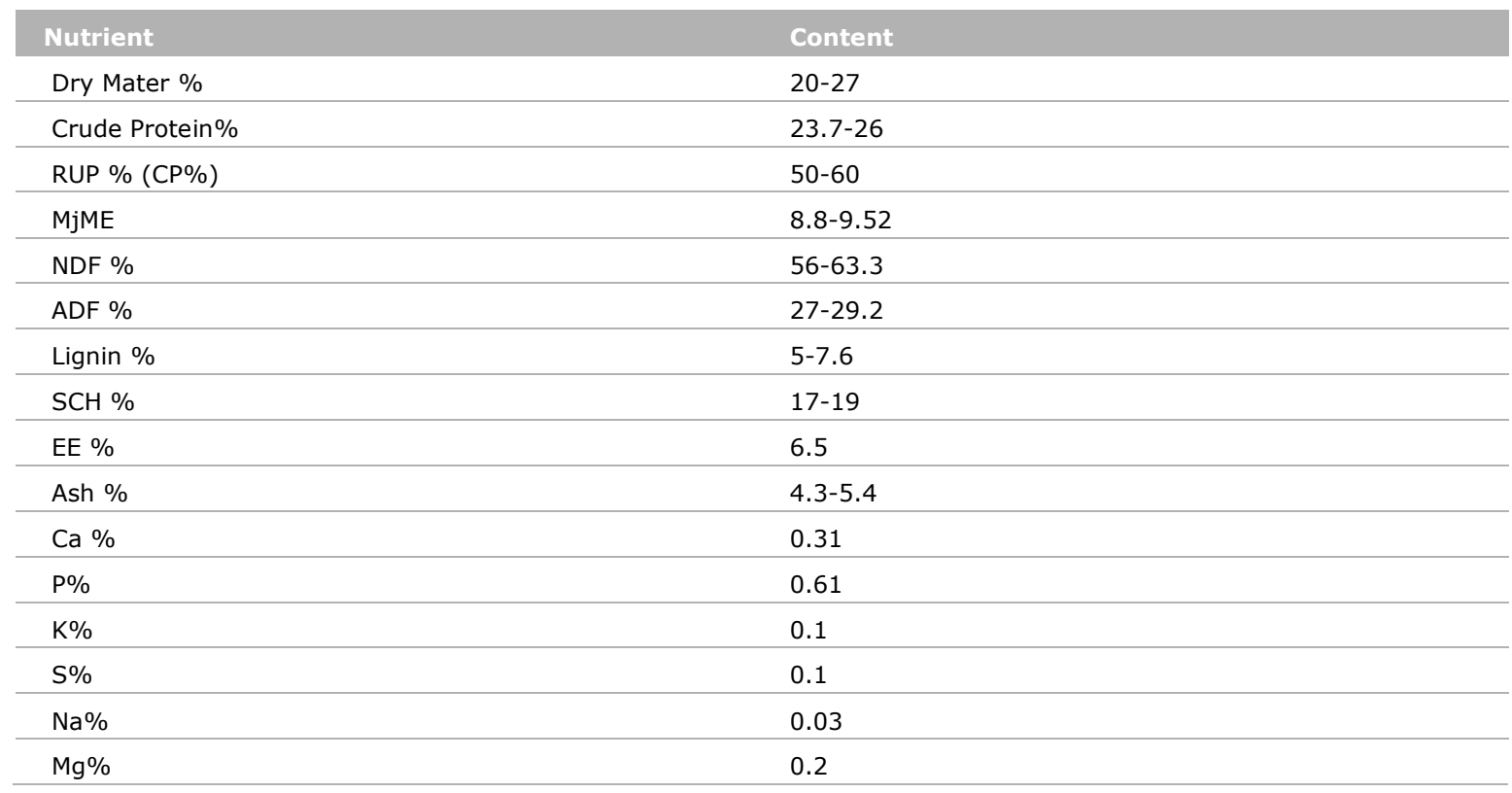

The spent brewery grain's crude protein averages $25 \%$ on DM. 50 to $60 \%$ of the crude protein bypasses the rumen without degradation, and thus this characteristic has to be considered when balancing the ration, especially in Ethiopian conditions where the amount of nitrogen available in the rumen for the microorganisms can be limited. Also, the low content of lysine has to be considered to balance amino acids in the diets.

The energy content can be between 8.8 to $10 \mathrm{MjME}^{1}$, this value being related with the content of lipids and soluble carbohydrates. In the context of Ethiopian dairy farms and their available feed, this energy value has to be considered as a very good value.

Spent brewery grain fiber does not have the "effective fiber effect" in the rumen, yet it has a positive effect on chewing time compared with other high fiber concentrate feeds. This is beneficial to the recycling of buffer substances in saliva, which may help decrease the risk of acidosis.

Because of the low calcium and potassium and high phosphorus contents, an adequate mineral supplement should be offered to growing cattle consuming spent brewery grains.

The short lifespan of the wet spent brewery grain is the critical problem of farmers when utilizing this by-product. Ensiling of wet brewery grain either alone or along with other feed is ecologically and economically feasible, and easily applicable from a technological view point to dairy farmers in Ethiopia. The selection of right conservation method is crucial for storing and utilizing this feed without spoilage.

\section{Spent Yeast}

During the fermentation process, yeast cells can multiply numerous times, which results in markedly greater yeast mass than what is added at the start of fermentation. The yeast growth rate is influenced by the fermentation conditions at each brewery. The typical volume of spent yeast collected from a lager fermentation is approximately $2 \mathrm{~kg} / \mathrm{hl}$ of the final volume of beer produced (Mathias et Al., 2014). Similar to spent grain, some breweries sell their spent yeast as animal feed.

The potential of spent yeast as a source of protein, minerals and B-complex vitamins, and high quantities of essential amino acids might provide additional opportunities to the farmers if used correctly.

\footnotetext{
${ }^{1}$ MjME: megajoules of metabolisable energy, usually measured per kilogram of dry matter (MJME/kg DM)
} 
The water content of this product is very high (88-90\%), and the main nutrients (Table 3 ) are in suspension, which difficult its direct use on farm, unless a special strategy aimed to address this matter is used. This should involve the homogenization of the product before being used (agitator, mixer, homogenizer). Again, conservation is another main issue to be considered due the very short feed out period, especially under Ethiopian conditions (3-5 days).

Table $3 \quad$ Nutritional composition of wet spent brewery yeast (source: Feedipedia).

\begin{tabular}{|c|c|}
\hline Nutrient & Content \\
\hline Crude Protein \% & $40-48$ \\
\hline RUP \% (CP\%) & $50-60$ \\
\hline MjME & 13.4 \\
\hline ADF \% & 2.5 \\
\hline Lignin \% & 0.8 \\
\hline $\mathrm{SCH} \%$ & 12.8 \\
\hline EE \% & $1-1.2$ \\
\hline $\mathrm{P} \%$ & 1.3 \\
\hline $\mathrm{K} \%$ & 3.4 \\
\hline $\mathrm{S} \%$ & 0.01 \\
\hline $\mathrm{Na} \%$ & 0.21 \\
\hline $\mathrm{Mg} \%$ & 0.24 \\
\hline
\end{tabular}

\section{DAIRY FARMS}

Milk production systems in Ethiopia could be classified into urban, peri-urban and rural (Reda, 2001). Both urban and peri-urban systems are located around Addis Ababa and regional towns, and benefit from the urban markets. The urban system consisted of 5,167 small, medium and large dairy farms producing about 35 million I of milk annually (FAO 2011).

Dairy productions systems have seen major changes over the past decade thought. The number of small scale farms with increasing specialization of milk production is growing strongly. Urban milk production still takes place in town, but is increasingly under pressure of urbanization and enforcement of public hygiene regulations. Medium to large scale farms have been emerging strongly, especially around Addis Ababa but increasingly also in smaller rural towns such as Bahir Dar, Hawassa, Mekelle.

Of the total urban milk production, 73 percent is sold, 10 percent is used for household consumption, 9.4 percent is used to feed calves and 7.6 percent is processed into butter and Ayib (a cottage type of soft cheese, crumbly in texture common in many parts of Ethiopia). Seventy one percent of the producers sell their milk directly to consumers. The peri-urban milk production system includes smallholder and commercial dairy farms in the proximity of Addis Ababa and other regional towns. This sector controls most of the country's improved dairy stock with F2 75\% cross breed.

Other characteristics of these urban and peri-urban dairy farms are the unavailability of land to grow fodder, reason for which the cow's diet is based on purchased feed. In all cases, the main forage is based on straw and hay, both with very low digestibility and nutrient content. The rest of the diet is based on by-products from the flour industry, oil industry, sugarcane industry, and brewers' industry. 


\section{Field survey}

\subsection{Materials and Methods}

A total of 61 dairy farms were surveyed. The questionnaire included queries on different aspects of the farm, these being mainly related with the use and management of spent brewery grain (Annexe 1). The survey was completed by a group of dairy advisors during the week of 18 June 2018 (week 25). These advisors were trained earlier on by the DairyBISS project in practical dairy farm management and communication skills.

\subsubsection{The Study Areas}

The study area included Addis Ababa, Amhara and the Oromia region (Hawasa, Adama, Mojo, Sebata, BahirDar, Asella, Kombolcha, Sendafa, Sululta, Bishoftu, and Holeta), all in the vicinity of breweries and because of the current use of spent brewery grain.

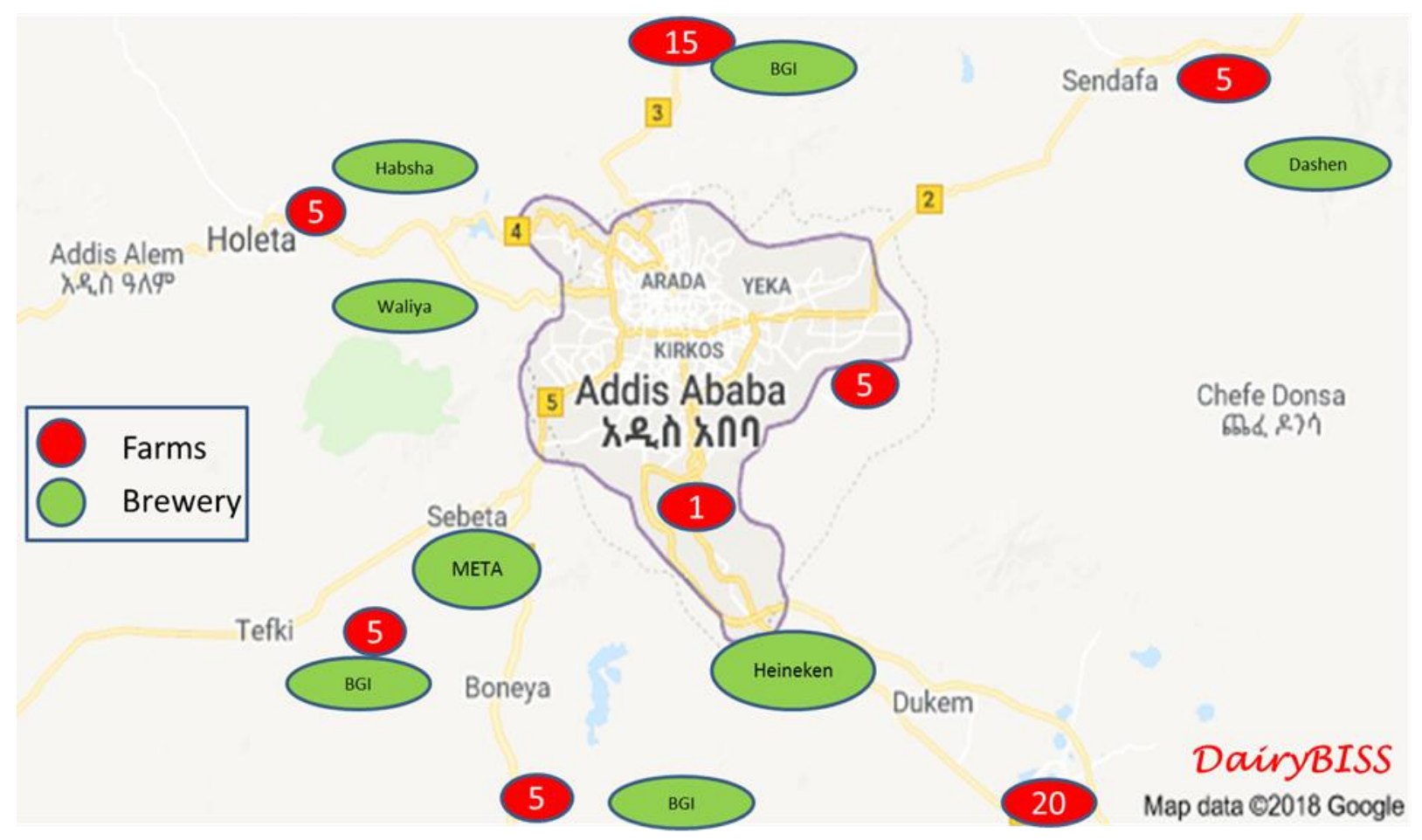

Figure 2 Study area.

\subsubsection{Data Collection}

The survey was implemented by the DairyBISS trained dairy advisors. A total of 13 advisors were preselected to do the survey; the selection was based on their knowledge and working area. The information collected during the farm interviews was forwarded gradually during the week of the survey so that it could be processed step-wise. After the collection of the survey a meeting with all the advisors involved was carried out so that any misinterpretation could be clarified and the data homogenised. At the end the data for a total of 61 farms was collected to be analysed. 


\subsubsection{Analysis}

The analysis of the data was organised to evaluate the current farm situation (numbers of cows, production, location and available land) and spent brewery grain management, feeding and storage (Figure 3).

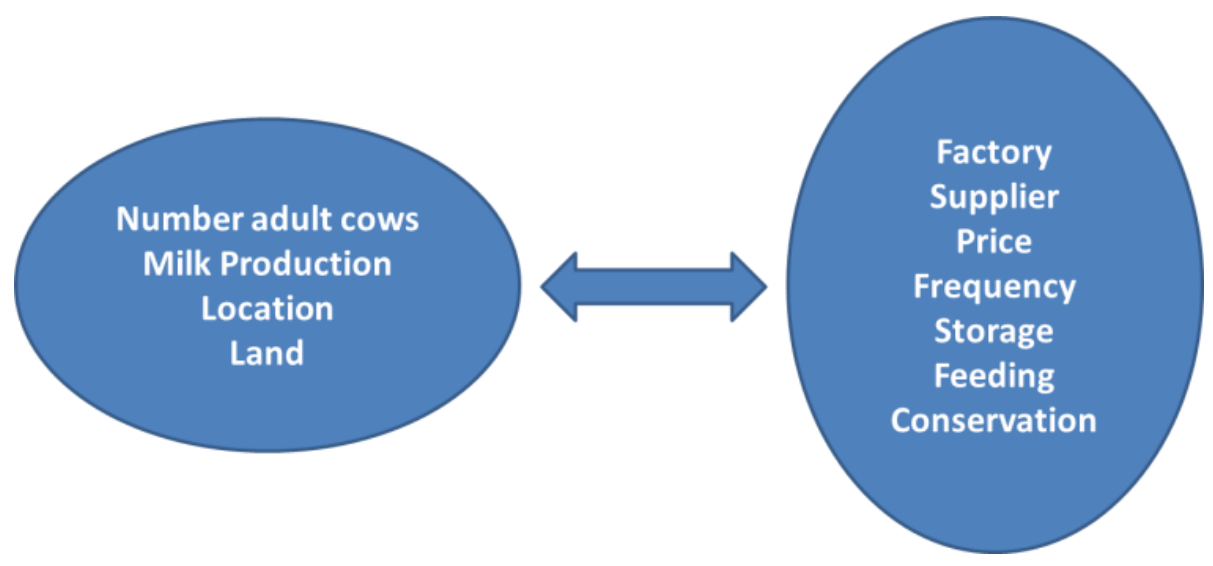

Figure 3 Scheme of data analysis and relationships.

\subsection{Results and Discussion}

\subsubsection{Factory and Supplier}

Based on the survey, the spent brewery grain used by the farms in the study area comes from the following factories: BGI, Heineken, Meta, Habesha, Waliya, and Dashen. The selection of the factory by the farmer was based on spent brewery grain availability as the main reason (100\%), followed by price and quality only in farms that have access to more than one factory (10\%). Factory and farm location is not a key factor when the spent brewery grain is purchased from retailers, given that the final price includes the transport cost. Those farmers that buy the product directly from factory always do so from the nearest factory.

The lack of transparency in the full chain of commercialization of spent brewery grain, from factory to farm through unions, retailers, whole sellers, and transport, makes it very complicated for farmers to plan and develop a strategy of storage and use of the product. At the same time this situation creates a very variable range of prices that generate confusion on the farmers. The exception to this situation was Kombolcha district (woreda), in the Amhara region, where farmers buy from BGI factory. In order to purchase the product from the factory, farmers need to be registered in the factory previously. It is mandatory to take a minimum of a full track $(5,000 \mathrm{~kg})$ and they have a fixed price of $0.7 \mathrm{EBr} / \mathrm{kg}$. The trucks are owned by the brewery factory and transport cost is included in the price. This is the only area where a good commercialisation system on place is found.

The Government has recently established new rules on this matter (Directives No 02/2018. Released in February 2018), with the aim of improving the commercialisation of spent brewery grain. At this moment, the supply of spent brewery grain through the year is very reliable, with only short periods of time (in the order of a week) in which the supply may stop due to maintenance works at the breweries. During the dry season, an increment in the demand of spent brewery grain can generate some scarcity of products for some farmers. This is due to the lack of alternative feed, especially for fattening and local cattle that usually do not use the product during the raining season. In the near future the supply of spent brewery grain could become a problem due the increment of the demand throughout the year, especially in dairy farms where spent brewery grain is an important component of the cow's diet all year around.

The current short-term capacity of storage (week-month) in the farms do not give farmers the possibility of generating enough storage so that any possible lack of product can be covered. 
To prevent this in the near future, an increase in the storage capacity will be a key point to be considered. The majority of farmers purchase the spent brewery grains through retailers or wholesalers; only $17 \%$ of them buy it directly from the factory (table 4 ).

Table 4 Type of supplier use by farms in the study area.

\begin{tabular}{ll} 
Type of Supplier & Farms \% \\
Factory & 17 \\
\hline Wholesaler & 37 \\
\hline Retailer & 46 \\
\hline
\end{tabular}

\subsubsection{Price}

The average price paid at the moment of the survey was $1.4 \mathrm{EBr} / \mathrm{kg}$, but the price can go from 0.6 to $3 \mathrm{EBr} / \mathrm{kg}$, and there is no direct relation between the price paid and either the amount purchased or frequency. This means that the price is basically the same disregarding the size of the farm. Also, this price variability without any apparent reason confirms the lack of transparency in the commercialization chain of spent brewery grain.

Table 5 reflects the variability in price based on the type of supplier (factory, wholesaler or retailer, Table 5).

Table $5 \quad$ Average price from different sources paid by farmers in the study area.

\begin{tabular}{lll} 
Source & Average $(\mathrm{BBr} / \mathrm{kg})$ & $\mathrm{Ratio}(\mathrm{BBr} / \mathrm{kg})$ \\
Factory & 1 & $0.7-1.5$ \\
\hline Wholesaler & 1.14 & $0.7-1.85$ \\
\hline Retailer & 2.45 & $0.7-3$ \\
\hline
\end{tabular}

Yet the average price of spent brewery grain is still very attractive compared with other available feed in the area (Table 6), but there is no real understanding of the "real price" of spent brewery grain. Nobody takes into consideration the particular nutrition characteristics of the product such as dry matter, protein or energy content, neither account for the product losses (5-20\% depending on management). This was very clear in the case of two farms that both are paying $3 \mathrm{EBr} / \mathrm{kg}(12 \mathrm{EBr} / \mathrm{kg}$ DM), price that exceeds any product price in the market.

Table 6 Comparison between common ingredients utilised in the study area.

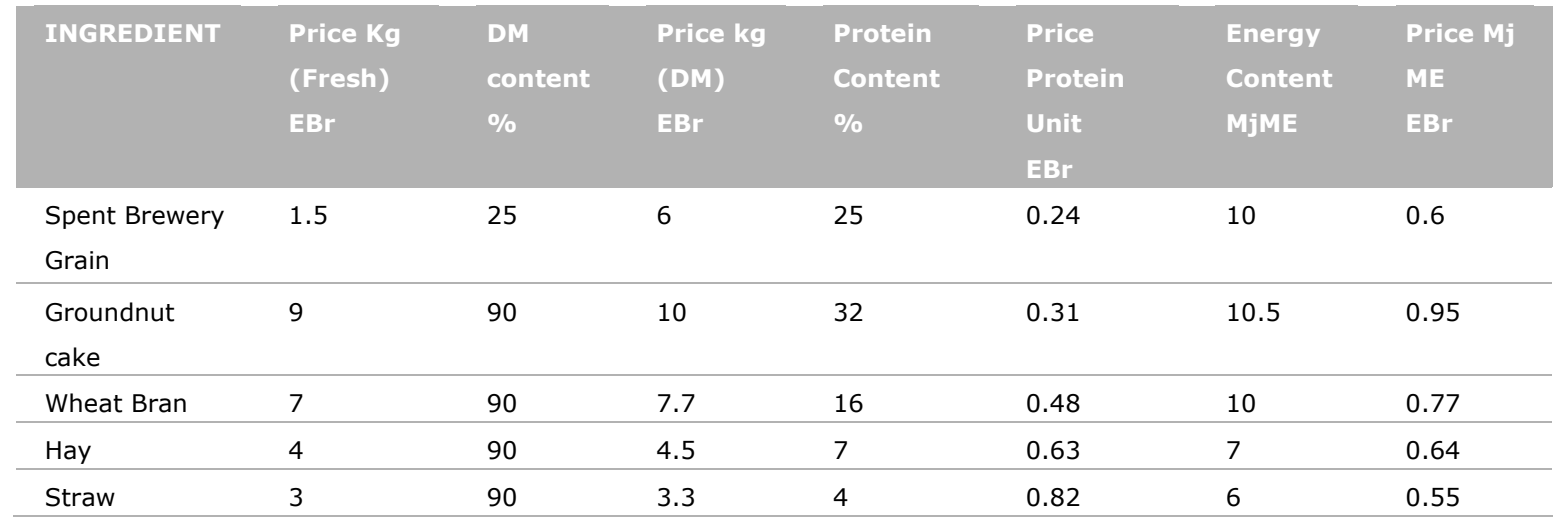




\subsubsection{Frequency}

The frequency of supply varies from weekly to monthly basis. The frequency is related with "product conservation".

The product is used fresh, and due its short feed out period, the amount of product stored depends not only on the numbers of animals and amount feeding, but also on the perishability.

\subsubsection{Storage and Conservation}

The storage facilities found on farms were concrete pit, plastic containers, plastic bags, homemade design and concrete floor (Table 7). The majority of the farmers that utilise concrete pit are medium and large farms. On the other hand, plastics containers and plastic bags are preferred by small farms. The homemade design (picture on the bottom right of the photo), wood structure with plastic walls, were exclusively found in Kombolcha woreda, with a capacity for $5,000 \mathrm{~kg}$ of product, which is the minimum amount sold by the factory in that area.

The product is used fresh and there is not much lost during its management by the farmers. According to the famers' experience, initially there was a big issue associated with the fast spoilage of the spent brewery grains, which caused health problems in some farms. Under current conditions, the conservation is based on storage capacity and consumption speed. Farmers remove the top layer of the spent brewers' grains storage to feed the animals twice a day, this process needs to be executed carefully to avoid the contact of air with the mass of the stored product. The depth of top layer that is removed daily should be $>15 \mathrm{~cm}$; if $<15 \mathrm{~cm}$ depth, the brewery starts to heat up. All farmers add salt to the top layer upon receipt of the product; four farmers also add water on top to improve conservation according to their own perception.

Table 7 Storage types in the study area.

\begin{tabular}{l|l} 
Storage type & Farms \% \\
Concrete pit & 56 \\
\hline Plastic container & 28 \\
\hline Homemade design & 8 \\
\hline Plastic bags & 7 \\
\hline Concrete floor & 1 \\
\hline
\end{tabular}

In the case of concrete pits, homemade design and concrete floor, the product never is covered. This means that the top area of the spent brewery grain is always in contact with air. In the case of plastic drums or bags the product is kept out of air contact until the storage is opened (Photo below). 


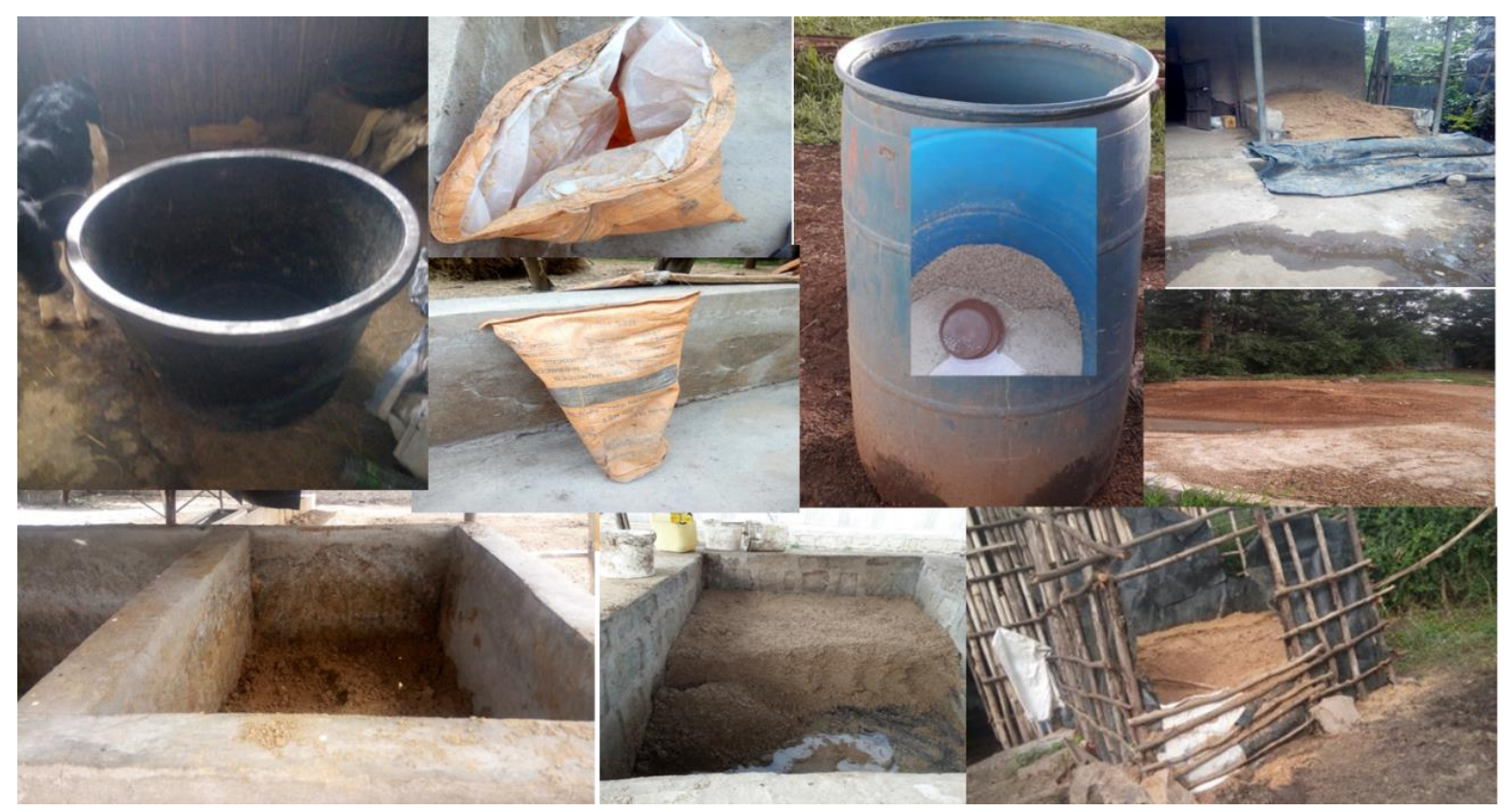

Figure 4 Different spent brewery grain storage methods used in the study area.

\subsubsection{Feeding}

Together with storage, feeding is another important gap in the utilization of spent brewery grain. Lack of knowledge in the product and how to use it was recognised for $100 \%$ of the farmers. This lack of knowledge drives them to feed based in their own experience. The farm advisor did not have any experience in the utilization of spent brewery grain either. The criterion on the amount to be fed is based on animal category: milking cows, dry cows, heifers and calves. This will also be determined by storage capacity and preservation. The way the feed is applied is also variable but all of the farmers feed twice a day and mixed with other feeds (Table 8), mainly with concentrate (wheat bran). A good number of them add water to the mix (photo below).

Table 8 Different ways used by farmers to feed the spent brewers grain in the study area.

\begin{tabular}{l|l} 
Way to Feed & Farms \% \\
Mix with concentrate & 54 \\
\hline Mix with forage & 1 \\
\hline Mix with Forage and concentrate & 34 \\
\hline Mix with water and concentrate & 10 \\
\hline Alone & 1 \\
\hline
\end{tabular}

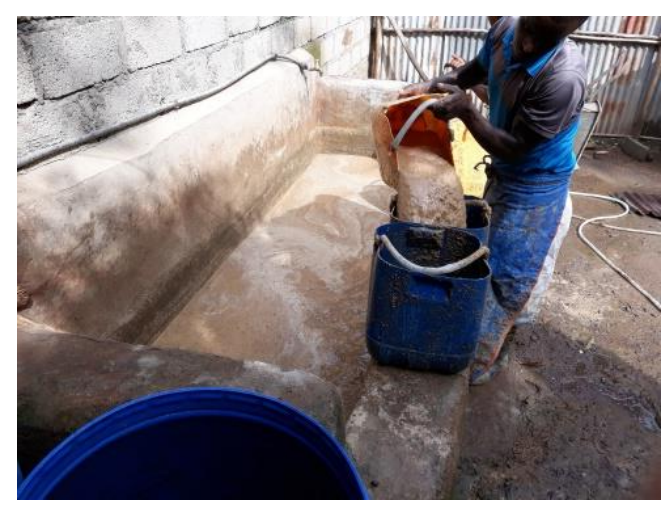

Figure $5 \quad$ Farmer mixing the spent brewery grains with water and concentrates. 
As mentioned before, it is evident that there is a lack of knowledge on the product and "how to use it". Farmers try to manage feed amount, storage, and supply only to avoid spoilage and loss of product, but there is no consideration on the nutritional aspect of the product or animal requirements. For all these reasons the amount of feed given to the animal within each animal category is completely uncontrolled (e.g., milking cow's rates range between 2 to $15 \mathrm{~kg}$ ). When considering between animal categories, the amount decreased from milking cows, dry cows, heifers, to calves. The main forages are straw and hay, both of which have a very low digestibility and nutrient content (table 6), but at the same time they are the only source of effective fibre in the diets. The availability of fresh forage is irrelevant in the total diet of the farms studied. The concentrates used in the area varies according with zone and industry by-product available, such as wheat bran, oil cakes, molasses, beans hulls, poultry litter and commercial dairy meal from different feed companies. The typical diet offered to lactating cows consists of forage based of hay and straw and a mix of different available concentrates (Figure 6);

ETHIOPIA

Ration title Dairy Cow ration

Animal details
Weight
Milk yield
Weight change
DMI Correction
Lactation week
Pregnancy week
Milk butter fat
Milk protein

\begin{tabular}{|c|c|c|c|c|c|}
\hline & & Reqs & Ration & Balance $\%$ & kg DM \\
\hline 550 & Dry matter Intake & 14.6 & 14.7 & 101 & \\
\hline 10 & $M E$ & 122 & 135 & 111 & \\
\hline 0.00 & $\mathrm{CP}$ & 120 & 136 & 113 & \\
\hline 1.00 & $\mathrm{Ca}$ & 38 & 70 & 183 & 4.7 \\
\hline 10 & $\mathrm{Mg}$ & 18 & 29 & 161 & 2.0 \\
\hline 0 & $\mathrm{P}$ & 25 & 76 & 305 & 5.2 \\
\hline 5.00 & NDF minimum & 42.0 & 56.0 & 133 & \\
\hline 4.00 & & & & & \\
\hline & & & & & \\
\hline & & & & & \\
\hline
\end{tabular}

\section{Suggested Ration}

\begin{tabular}{l|c|c|}
\cline { 2 - 3 } $\begin{array}{l}\text { Ration compone nt } \\
\text { Hay D50-55 }\end{array}$ & Fresh kg & DMI kg \\
\cline { 2 - 3 } $\begin{array}{l}\text { Wh Straw } \\
\text { Brewers Grains }\end{array}$ & 4 & 3.4 \\
\cline { 2 - 3 } $\begin{array}{l}\text { Wheat Bran } \\
\text { Cake 27\% }\end{array}$ & 6 & 3.48 \\
\hline Dairy Meal & 4 & 1.68 \\
\hline & 2 & 3.48 \\
\hline
\end{tabular}

\begin{tabular}{|l|c|}
\hline Forage intake (kg DM) & 6.9 \\
\hline Concs intake (kg DM) & 7.8 \\
\hline Forage NDF (\% DM ) & 35.3 \\
\hline
\end{tabular}

Figure 6 Average lactating dairy cow diet in the study area (*Dairy meal: 16.5\%CP, 12 MjME).

These types of diets can usually cover a production of around $10 \mathrm{l} /$ day. The main nutrients limiting production are energy and protein. The forage sources (hay and straw) are low quality and have a low digestibility that clearly limits the total dry matter intake and productivity of the animals.

Spent brewery grain can significantly help improve the nutrient balance of the diets. First of all, it allows the partial replacement of low digestible forage and of some of the by-products used (wheat bran, bean hulls). These changes will decrease the Neutral Detergent Fibre \% (NDF) and increase the protein percentage and energy content in the total diet. As a consequence of this modification, there will be an increase in dry matter intake and milk production.

In most farms, the current amount of feed offered to milking cows can be increased by decreasing the NDF offered. This can be done by replacing high NDF ingredients with spent brewery grains. However, main constraints to that increase are storage capacity and frequency in the supply.

As mentioned before, spent brewery grain is given to all animal categories, but there is no control in the amount offered to the animals and, as a result of that, a to heavy condition heifers and calves was observed. This could affect animal growth and development of the replacement animals and have an effect in the potential production in the long run. 


\subsubsection{Farmer perception}

All farmers agree in the positive effect that spent brewery grains has on their cows, mainly due the increment in production, and better coats and condition of the animal. Farmers also recognise the high palatability of the product, a characteristic that gives the advantage of mixing it with less palatable feed to improve the intake of this. The difficulties for good conservation and heating up of the product during storage are their major concern, together with the lack of knowledge on how to feed the spent brewery grains in combination with other feed ingredients. The perception from the farmers on the quality of the product from the different factories is related with conservation characteristics, as they considered that a high moisture spent brewery grain and smaller particles size (easy to press) are good qualities. 


\section{Conclusions}

The dairy production system developed in Addis Ababa, Amhara and Oromia region - mostly being urban and peri-urban farms - is based on purchased feed (90-100\%).

Forage constitutes more than $50 \%$ of the total diet and consists of very low digestible hay and straw; the other $50-40 \%$ is completed with concentrates available in the area, which are mainly based on individual feed ingredients produced as by-products of flour and oil processing industries, and different locally available by-products (bran, middling \& other cereal grain mill by-products, oilseed cakes and meals, hulls, and screenings). Spent brewery grain is also used as concentrate in many farms at an average inclusion of $10 \%$ DM of the total ration. From the nutritional point of view the high NDF\% content of the diet negatively affects the "total dry matter intake" and the supply of nutrients to enhance milk production. Improving the utilization and management of spent brewery grain in the diets can play a positive role in the quality of the total diet and help increase production and profitability of the dairy farms. The particular characteristics of the diet of lactating cows in the area are high NDF, low digestibility, low protein, low energy, and low rumen degradable protein. In order to increase the efficiency in the use of spent brewery grain, it is important to consider the positive and negative aspects of it within the Ethiopian context (Table 9) (Annexee 2).

Table 9 Positive and negative aspects of spent brewery grain under Ethiopia context.

\begin{tabular}{ll} 
Positive & Negative \\
Moisture Content & Conservation \\
\hline Palatability & Low RDP* content \\
\hline Protein Content & Low Calcium content \\
\hline Energy Content & Low Potassium content \\
\hline
\end{tabular}

High Phosphorus Content

*Rumen degradable protein

The challenges associated with the improvement in the use and management of spent brewery grain in Ethiopian dairy farms combined different aspects, all of them interrelated (Figure 7).

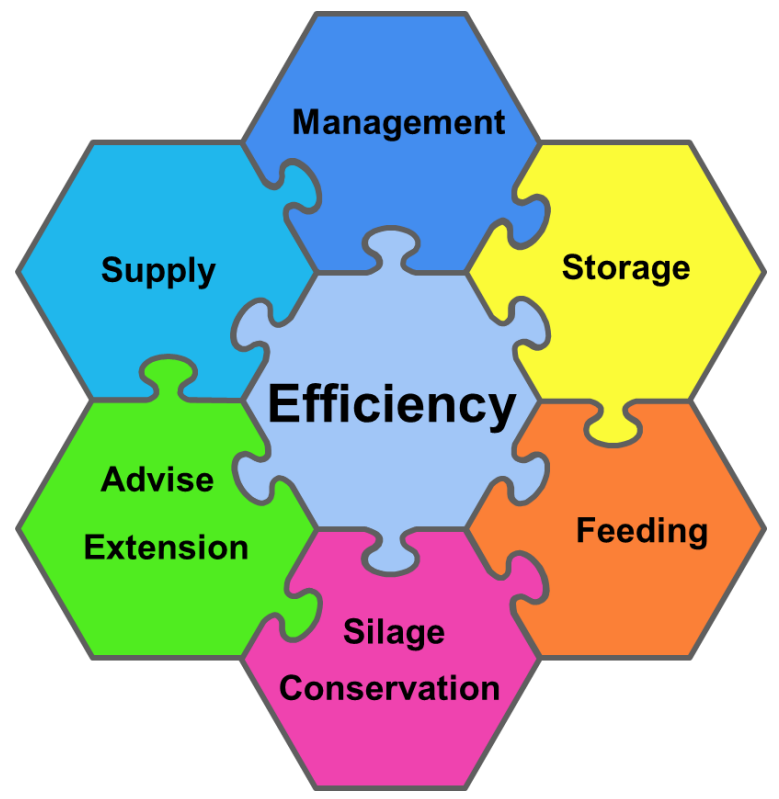

Figure 7 Different aspects to be considered to maximise the use of spent brewery grain in Ethiopian dairy farms. 
Supply: In the future, it will be important to create a transparent market around spent brewery grain. Different tools could be developed by the stakeholders to attain this objective (contracts, agreements, transport condition, timing, and quality standards).

At the moment, under the existing market chain situation, an increase in the storage capacity on farm, silage of breweries grain, and farm feed budgeting are the tools available to be implemented by farmers until "stakeholder's interconnection" improves.

Storage and Silage: Increase storage capacity will allow for a better management as well as shortening the supply time between factory and farm, especially during the dry season or during factory maintenance; it will also put the farmers in a better position to negotiate the price. An increase in the storage capacity can be achieved by the production of spent brewery grain silage. Given the fast spoilage of the product, this is simplest method for long-term conservation. Another advantage of silage under the Ethiopian conditions will be the possibility of combining wet spent brewery grains with crop residues such as straw or hay during the silage process.

Silage Dimensions and Design: Considering that (i) a cubic meter of wet spent brewery grain weighs about $800 \mathrm{~kg}$ and that, to avoid spoilage, (ii) the need to maintain a rapid progression through the silage face (the rule of thumb is to remove between $12-15 \mathrm{~cm}$ per day), and (iii) considered a 21 days silage process, the size of the storage will need to be dimensioned. Plastic drums provide better storage conditions, especially for small holder urban dairy farmers but they have to be covered with a lid and sealed with tape to avoid any air contact with the product silage; another option for small farms could be the use of plastic bags filled with the product and very well sealed.

Silage Process: Crop residues have complementary characteristics to brewery grain as they are low in energy, protein, fat, phosphorus and sulphur, and the digestibility of the fibre in these feeds is also low. The deficiencies and excesses of each feed thus balance when they are blended together in the diet. This can be accomplished by mixing and ensiling them together. This approach poses challenges, as the particle size of the roughage fraction needs to be reduced sufficiently $(2-3 \mathrm{~cm})$ to exclude air as much as possible during ensiling.

The ratio at which both feeds are added needs to be such that enough moisture is provided to assist in compaction and fermentation. Actual fermentation of these blends is limited due to minimal amounts of water soluble carbohydrates. It is important to realize that because of this limited fermentation, we rely on the initial $\mathrm{pH}$ of the spent brewers' grain to enhance preservation of the blends $(\mathrm{pH}<3.5)$. The moisture content of the ensiled blend should be at least $50 \%$. However, moisture content above $75 \%$ may be harmful as undesirable fermentation may occur in later stages of the ensiling procedure, resulting in sour silage, hence reducing palatability. Also, due the fact that ensiling has not been practiced before in this area, the method should be kept as simple and accessible as possible (Annexe 3).

Drying is a possible option to consider for spent brewery grain preservation with the advantage that it also reduces the product volume and, therefore, decreases transport and storage costs. Also marketing dry spent grain instead of wet spent grain opens a new market to the factories with a focus on feed companies for a potential use in mono gastric animals. Studies on drying cost, process and market need to be done prior to implement this option, especially due the extra cost involved in the process.

Feeding and Management: For the lactating dairy cows increasing the amount in the total diet from the actual average of $10 \%$ to $25 \%$ of the total diet dry matter will be possible without any risk for animal health point of view. This increment would give the opportunity to replace low-quality forage, especially straw and reduce the amount of concentrate used (especially wheat bran or hulls) this change in the ingredients will improve nutrient balance and enhance production without increasing total diet cost or animal condition. The mix of spent brewery grain with concentrates and forage before being offered to the animals also will contribute to a better feed utilization and rumen function, like a "total mix ration" that will cover a minimum milk production and cows over that production can be 
supplement with a commercial local meal that will cover those extra requirements according with yield (Annexee 4).

For replacement categories (heifers and females calves), it is critical to reduce the amount offered, as the over conditioning of these animals will affect negatively their future milk production potential. The amount offered to heifers ( $>$ 1year old) must be limited to 3 to $4 \mathrm{~kg}$ and for calves (4 to 12-monthold) to 1 to $2 \mathrm{~kg}$ of fresh spent brewery grain.

Extension: Different extensions tools should to be used at different levels to improve the efficiency in the use of the spent brewery grain.

Training of farm advisors and provision of technical information on storage, management and feeding techniques related with spent brewery grain, storage design and adequate dimension, silage techniques and management, feed budgeting (Annexe 5), feeding management.

Supplying practical information and advice to farmers will allow an increase in the efficiency in the use of spent brewery grain. 


\section{References}

Demissie Chanie1*, Veerle Fievez. DOI: 10.14737/journal.jahp/2017/5.1.10.13Review on Preservation and Utilization of Wet Brewery Spent Grains Concentrate Replacement Feed for Lactating Dairy Cows.

FAO (Food and Agriculture Organization). 2011. Food Balance Sheets. FAOSTAT. Rome. (http://faostat3.fao.org/download/FB/FBS/E)

FAO (Food and Agriculture Organization). 2014. Food Balance Sheets. FAOSTAT. Rome. (http://faostat3.fao.org/download/FB/FBS/E).

FAO (Food and Agriculture Organization). 2017. Livestock Feeding Action Plan, HarinderP.S. Makkar, Alberto Giani, FAO Ethiopia. Addis Ababa.

FAO (Food and Agriculture Organization). 2011. A Review of the Ethiopian Dairy Sector. FAO Sub Regional Office for Eastern Africa (FAO/SFE).

Feedipedia, Animal feed resources information system. Feedipedia.org

Fekede Feyissa et al, /Eth. J. Anim. Prod. 15(1)-2015:17-30.Mineral profiles of agro-industrial byproducts and locally available supplementary feeds and their implications for dairy cattle nutrition in Ethiopia.

Kaso T, Guben G. 2015. Review of barley value chain management in Ethiopia. J Biol Agric Healthc. 5:84-97.

Mathias dos Santos Thiago Rocha. Pedro Paulo Moretzsohn de Mello. Pedro Paulo Moretzsohn de Mello. 2014 Solid wastes in brewing process: A review." Journal of Brewing and Distilling 5, no. 1 (2014): 1-9.

Redda,Tsehay. 2001. Small-scale Milk Marketing and Processing in Ethiopia. In: Proceedings of the South - South Workshop on Smallholder Dairy Production and Marketing - Constraints and Opportunities. March 12th -16th 2001, Anand, India.

Solomon Demeke Jimma, University College of Agriculture and Veterinary Medicine. Livestock Research for Rural Development 19 (1) 2007.Comparative nutritive value of Atella and industrial brewers grains in chicken starter ration in Ethiopia. 


\section{Annexe 1 Questionnaire to collect data on brewer's grain utilization from sample dairy farms}

Objective: to analyse storage and utilization of brewers grain on dairy farms in various milk sheds in Ethiopia.

The analysis is a quick scan, which should not take more than half an hour of observations and interactions on farm (with owner, manager or workers).

Type of information required:

1. some background information on the farm: number of (dairy) cows, current feeding practices

2. source, storage and utilization of brewers grain on the farms.

1. General Information

1.1. Full name of the farmer

1.2. Name of the farm (if applicable)

1.3. Location of the farm

- Region

- Zone

- Woreda

2. Dairy animals

2.1. How may dairy animals you have

2.2. Type of dairy animals

- Lactating cows

- Dry cows

- Heifer older than one year

- Female calves

- Male calves

- Bull

2.3. Breed of your cows

- 100 local breeds

- F1 50\% cross breed

- F2 75\% cross breed

- More than $90 \%$ exotic

- Exotic

2.4. Milk production

- Average production of farm per cow/litre/day

- Average production of cow per lactating period /litre

- Average length of lactating period /day

2.5. Size of farm/hac

2.6. Types of crops grown (if applicable)

2.7. Types of fodder grown (if applicable )

2.8. Feed ingredients/sources used on farm

Types of feed

Roughage

- Straw

- Hay

- Silage

- Grazing
Source

Own

Purchased 
- Others specify

Factory by

products

- Oilcake

- Brewery

residual

- Wheat/rice

bran

- Salt

- Others specify

Water

2.9. Do you have group feeding system

Yes $\square$

No $\square$

2.10. What are normal rations used on farm

- Lactating cows

- Dry cows

- Heifer older than one year

- Female calves

- Male calves

- Bull

3. Brewery residual

3.1. What kind of brewery residual you use for dairy feeding

Spent grain $\square$

Yeast

3.2. List brewery factories that you used as sources of brewery residual (put by ranking if it is more than one )

3.3. What are the main reasons you use the specific factory by product (multiple answer is possible)
Availability $\square$
Quality
Price
Reliability $\square \quad$ other specify

3.4. How do you get the by products

Wholesaler

Retailer $\square$

Directly from Factory $\square$

other specify $\square$

3.5. For how long you utilize the brewery residual as animal feed?

3.6. Is there any incidence that you stopped utilizing the brewery residual as animal feed ? and why?

3.7. How much usually bought from sources and how often ?

3.8. How much it costs/kg

3.9. How much the transport cost from sources to your farm

3.10. How is the availability in different season

3.11. How the brewers grain is stored on the farm

3.12. What are the criteria to feed your animal brewery residual

Production level, Age

Blood level other

3.13. what is usual storage period before feeding

3.14. How you feed brewers grain:

Separately $\square$ in mixtures of roughage $\square$ in mixture of concentrates $\square$ other specify $\square$

3.15. What is the main reason that you choose the specific way to feed brewer residual to your dairy cows

3.16. Have you faced losses during conservation and feeding 
3.17. How you could preserve the brewery residual

3.18. What are the challenges and opportunity to fed brewer grain for dairy cows

3.19. In general: what is the opinion on use of brewer's grain by interviewee? 


\section{Annexe 2 Spent Brewery Grain Nutritional Characteristics to be considered under Ethiopian Dairy System Conditions}

The high concentration of fibre in the spent brewery grains is related to the fact that simple sugars and starch are removed from the grain during the malting process leaving behind mainly the structural carbohydrates (cellulose, hemicellulose), It is the high digestible fibre what mainly contributes to its total energy value together with its additional fat content (7-10\%).

The main forages used in Ethiopian dairy farms are very high in neutral detergent fibre (NDF) (Table S1), and low in digestibility. Also, due to the lack of mechanisation, it is provided in large particle size and this has a high "gut-feeling" effect without contributing much to dietary nutrients. This makes difficult the achievement of the desired nutrient balance, as needed to enhance production.

Table S1 NDF\% and eNDF\% $\%^{2}$ content in some common Ethiopia dairy cows ingredients.

\begin{tabular}{lll} 
Ingredient & NDF\% (in DM) & eNDF(\%) \\
Spent Brewery Grain & 45 & 18 \\
\hline Wheat Straw & 81 & 98 \\
\hline Hay & 72 & 98 \\
\hline Wheat Bran & 46 & 4 \\
\hline
\end{tabular}

In this regard, spent brewery grain can play a key role in partially replacing traditional forages, thus increasing the nutrients density of the diet, while maintaining enough effective fibre and chewing activity to ensure saliva production and rumen function. In case of scarcity of traditional forage due an environmental emergency such as a long period of drought, it can be used to replace almost the totality of the hay or straw.

Also, due the high price of wheat bran its partial replacement with spent brewery grain can be considered. The similar value in fibre digestibility and energy, plus the better protein value of the brewery grain, makes it an interesting product to replace partially the use of wheat bran.

The low content of soluble protein in the Ethiopian milking cow's diets is another important point to carefully consider when evaluating the inclusion of spent brewery grain in the diet. $50 \%$ of the total proteins of brewery grain by-pass the rumen without degradation. In order to keep a high rumen efficiency and promote the growth of rumen's microflora a source of available nitrogen and energy with similar speed of degradation needs to be provided. Both components are deficient in Ethiopia standard lactating cow diets. In order to overcome this, soluble protein and soluble sugars sources have to be added to the diet, especially if spent brewery grain is used as feed. Sugar source like molasses are available in Ethiopia and have to be considered. Nitrogen sources such as urea or poultry litter should also be considered.

From the mineral balance point of view, more local research and investigation is needed to have a more in-depth knowledge of mineral content in the cattle diets.

\footnotetext{
${ }^{2}$ eNDF is a measure for the effectiveness of the fibre in the feed for rumen functioning.
} 


\section{Annexe 3 Silage}

The possibility to ensile spent brewery grain with low quality forages can be an excellent opportunity to improve the use of the feed silages. The mix with straw and spent brewery grain in different ratios can give a better balanced basic feed for the animals. It will also allow the incorporation of a fraction of brewery yeast, which given its characteristics, will improve feed utilization.

Examples of these combinations are shown in Table S2. The addition of $1 \mathrm{~L}$ of liquid yeast for each 10 $\mathrm{kg}$ of straw: brewery grain mix increases the CP\% of the silage in $1 \%$. The yeast will also act as a mycotoxin binder and immunity booster.

Table 52 Silage composition with alternative combination of straw: brewery grain: brewery yeast.

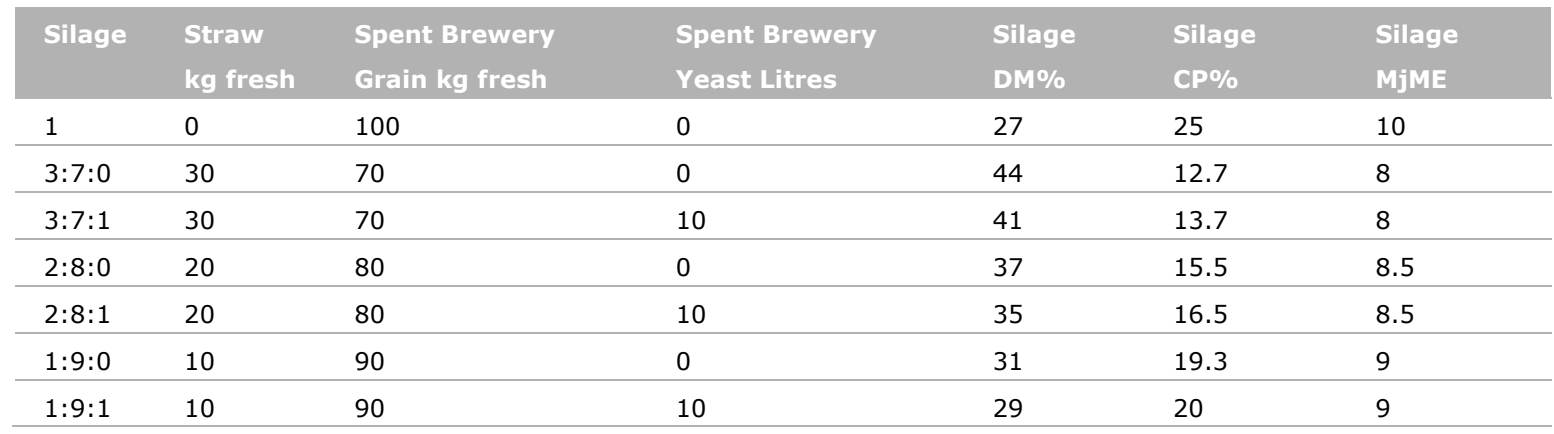

The combination of straw: brewery grain: brewery yeast by either 1:9:0 or 1:9:1 can be a very good option to be implemented in the Ethiopian dairy system. Due the lack of mechanisation, chopping the straw is not possible at this stage so it would be ideal to maintain the straw added at around $10 \%$ of the mix. These mixtures have a very good content of crude protein and energy. 


\section{Annexe 4 Feeding management}

Due to the particularities of the feeding systems used in the Ethiopian farms, some feeding management tools and practices could be improved so that the use of spent brewery grain can contribute to increase the total diet efficiency.

The mix of wet breweries with other ingredients before feeding can enormously help increase total dry matter intake and rumen feed utilization. Ideally this diet will be a mix of ingredients including forages and concentrates. The commercial "dairy meal" currently purchased will be excluded from the mix due to its high value. This "dairy meal" will be individually added on top, based on milk production. An example of the "total mix ration" intended to cover 14 I production could be the one shown in Figure S1. That specific mix could cover the requirements of 14 I producing cows. Cows producing more than 14 I will need to be supplemented with $1 \mathrm{~kg}$ of dairy meal ( $17 \%$ crude protein and $12 \mathrm{MjME}$ content) every 2 extra litres to a maximum of $8 \mathrm{~kg} /$ day for cows producing more than $30 \mathrm{I}$.

\begin{tabular}{|c|c|c|c|c|c|c|}
\hline \multirow{9}{*}{$\begin{array}{l}\text { Animal details } \\
\text { Weight } \\
\text { Milk yield } \\
\text { Weight change } \\
\text { DMI Correction } \\
\text { Lactation week } \\
\text { Pregnancy week } \\
\text { Milk butter fat } \\
\text { Milk protein }\end{array}$} & \multicolumn{3}{|r|}{ Reqs } & \multirow{2}{*}{$\begin{array}{r}\text { Ration } \\
15.1 \\
\end{array}$} & \multirow{2}{*}{$\begin{array}{c}\text { Balance } \% \\
101\end{array}$} & \multirow[t]{2}{*}{$\mathrm{kg} \mathrm{DM}$} \\
\hline & 550 & Dry matter Intake & 15.0 & & & \\
\hline & 14 & ME & 144 & 144 & 100 & \\
\hline & 0.00 & CP & 128 & 151 & 118 & \\
\hline & 1.00 & $\mathrm{Ca}$ & 45 & 57 & 126 & 3.8 \\
\hline & 10 & $\mathrm{Mg}$ & 21 & 29 & 138 & 1.9 \\
\hline & 0 & $\mathrm{P}$ & 30 & 78 & 255 & 5.2 \\
\hline & 5.00 & NDF minimum & 40.8 & 56.6 & 139 & \\
\hline & 4.00 & & & & & \\
\hline & & Fats maximum & 3.1 & 3.6 & 114 & \\
\hline
\end{tabular}

\section{Suggested Ration}

\begin{tabular}{l|c|c|}
\cline { 2 - 3 } $\begin{array}{l}\text { Ration com pone nt } \\
\text { Hay D50-55 }\end{array}$ & Fre sh kg & DMI kg \\
\cline { 2 - 3 } $\begin{array}{l}\text { Wh Straw } \\
\text { Brewers Grains }\end{array}$ & 3.5 & 2.975 \\
\cline { 2 - 3 } $\begin{array}{l}\text { Wheat Bran } \\
\text { Cake 27\% }\end{array}$ & 3 & 2.61 \\
\hline $\begin{array}{l}\text { Dairy Meal } \\
\text { Molasses Cane } \\
\text { UREA }\end{array}$ & 15 & 4.2 \\
\hline
\end{tabular}

\begin{tabular}{|l|c|}
\hline Forage intake (kg DM) & 5.6 \\
\hline Concs intake (kg DM) & 9.5 \\
\hline Forage NDF (\% DMI) & 27.7 \\
\hline
\end{tabular}

Figure S1 Example of a base of a total mix ration for Ethiopian dairy farms. 


\section{Annexe 5 Feed budgeting}

A yearly feed plan for each farm needs to be developed so that Ethiopian farmers are better organised. A feed budgeting is very simple to carry out when the numbers of animals and their respective categories are known. Once available, it is possible to estimate feed and nutrients requirements. Then, based on these requirements, the amount of feed and nutrients needed according with the season target production will be known. Farmers will then be able to plan the purchase of feed as needed to cover those requirements (Figure S2). Figure S3 shows an example of an annual feed budget for a farm with 10 milking cows, 3 heifers and 3 calves.

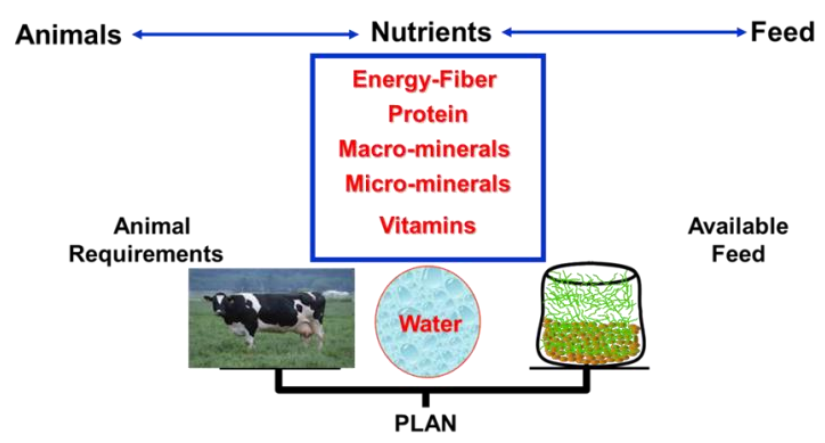

Figure S2 Scheme of feed budget plan.

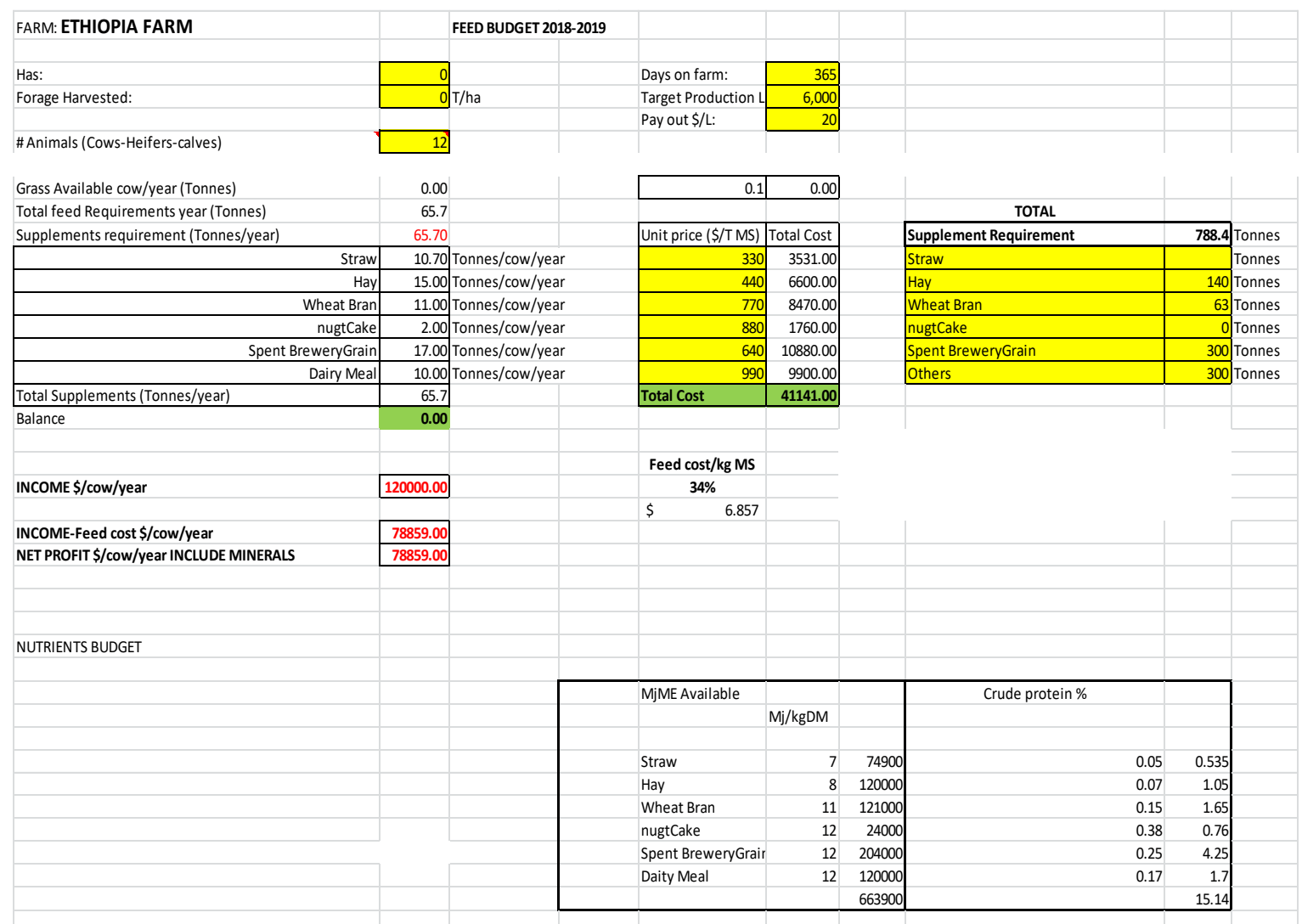

Figure $\mathbf{S 3}$ Example of Feed Budget for Ethiopian dairy farms. 

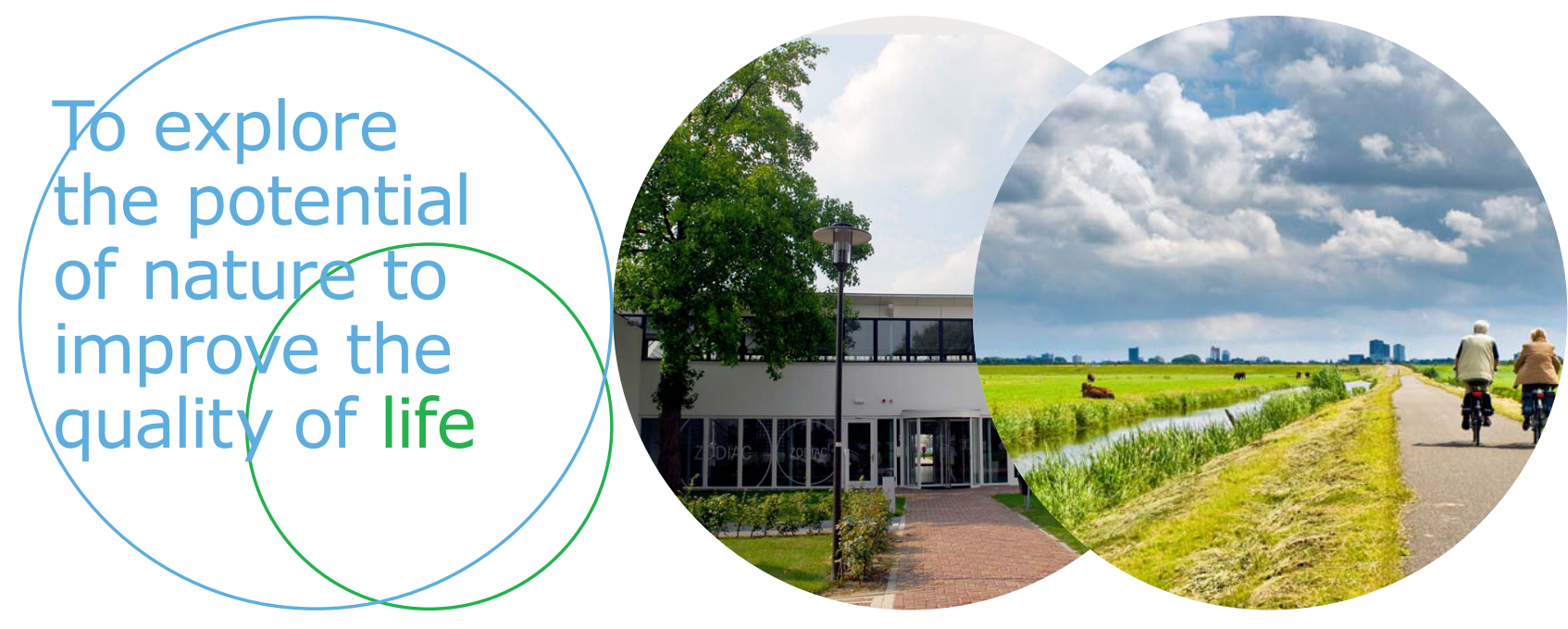

Wageningen Livestock Research P.O. Box 338

6700 AH Wageningen

The Netherlands

$\mathrm{T}+31(0) 317483953$

E info.livestockresearch@wur.nl

www.wur.nl/livestock-research

Wageningen Livestock Research creates science based solutions for a sustainable and profitable livestock sector. Together with our clients, we integrate scientific knowledge and practical experience to develop livestock concepts for future generations.

Wageningen Livestock Research is part of Wageningen University \& Research. Together we work on the mission: 'To explore the potential of nature to improve the quality of life'. A staff of 6,500 and 10,000 students from over 100 countries are working worldwide in the domain of healthy food and living environment for governments and the business community-at-large. The strength of Wageningen University \& Research lies in its ability to join the forces of specialised research institutes and the university. It also lies in the combined efforts of the various fields of natural and social sciences. This union of expertise leads to scientific breakthroughs that can quickly be put into practice and be incorporated into education. This is the Wageningen Approach. 